\title{
Effects of surrounding objects on the thermal performance of passively ventilated greenhouses
}

\author{
Edwin Andrés Villagrán, ${ }^{1,2}$ Carlos Ricardo Bojacá ${ }^{3}$ \\ ${ }^{1}$ Faculty of Engineering, Minuto de Dios University Corporation, Cundinamarca; ${ }^{2}$ Department of Biological and \\ Environmental Sciences, Faculty of Natural Sciences and Engineering, Jorge Tadeo Lozano University, Bogotá; \\ ${ }^{3}$ Department of Basic Sciences and Modelling, Faculty of Natural Sciences and Engineering, Jorge Tadeo Lozano \\ University, Bogotá, Colombia
}

\begin{abstract}
The growing expansion of protected horticulture in many regions is occurring around densely populated areas where land for agriculture is scarce, expensive or is used for other purposes. Inexpensive plastic passively ventilated greenhouses are the common choice for protected cultivation in these developing regions. The objective of this work was to analyse the effect of surrounding constructions and natural obstacles on the thermal performance of two naturally ventilated greenhouses. A saw tooth type greenhouse (TCG), typical for Colombian production, and an optimised greenhouse $(O G)$ alternative with greater ventilation areas were analysed using computational fluid dynamics (CFD) with and without the surrounding objects of a real environment. The results showed that air exchange rate of a greenhouse with restricted ventilation areas are greatly reduced when neighbouring objects are high enough. This ventilation restriction is intensified under low wind speed conditions. The temperature gradients of the $O G$ green-
\end{abstract}

Correspondence: Carlos Ricardo Bojacá, Department of Basic Sciences and Modelling, Faculty of Natural Sciences and Engineering, Jorge Tadeo Lozano University, Bogotá, Colombia.

Tel.: +57.1.2427030.

E-mail: carlos.bojaca@utadeo.edu.co

Key words: Airflow; computational fluid dynamics; protected horticulture; sawtooth greenhouse; ventilation rate.

Acknowledgements: the present study was funded by the Sistema General de Regalías and the Gobernación de Cundinamarca through the project Fortalecimiento de la competitividad del sector floricultor colombiano mediante el uso de ciencia, tecnología e innovación aplicadas en el departamento de Cundinamarca code: BPIN2013000100217.

Contributions: the authors contributed equally.

Received for publication: 21 March 2018.

Accepted for publication: 10 August 2018.

CCopyright E.A. Villagrán and C.R. Bojacá, 2019

Licensee PAGEPress, Italy

Journal of Agricultural Engineering 2019; L:856

doi:10.4081/jae.2019.856

This article is distributed under the terms of the Creative Commons Attribution Noncommercial License (by-nc 4.0) which permits any noncommercial use, distribution, and reproduction in any medium, provided the original author(s) and source are credited. house were lower than those of the $T C G$ scenarios due to the increased ventilation rates. The rooftop ventilation index for the $O G$ greenhouse was increased by $65 \%$ with respect to the $T C G$ greenhouse index, resulting in a direct effect on the ventilation rates. An improved air exchange with the outside can be reached by increasing the greenhouse ventilation areas, especially the roof vents, to overcome the airflow restrictions imposed by the surrounding environment. This simulation exercise was validated with field temperature data collected for a real $O G$ prototype built in the Bogota plateau, with results showing a similar pattern for the internal temperature gradient as exhibited by the CFD model.

\section{Introduction}

Globally, greenhouse horticulture is expanding at a fast rate with more than 55 countries growing commercial crops under protected conditions (Reddy, 2016). Nowadays, world greenhouse production is established on an estimated area of 405,000 ha (FAO, 2013), located mainly in Asian countries (e.g. China, Korea, Japan), regions such as the Mediterranean basin or large production clusters such as the Westland in the Netherlands. The extensive use of inexpensive plastic greenhouses largely surpasses the cropped area under high-tech glasshouses.

Plastic greenhouses have become the predominant choice for protected cultivation in mild-winter climates and other warm regions of the world (Castilla, 2002). Despite its variations, plastic greenhouses are characterised as low cost, passively ventilated and unheated structures with minimal to none use of active climate control systems (Tuzel et al., 2017). These greenhouses largely depend on the outer climate; therefore, the climate control is limited to regulating the air exchange with the exterior through the vents.

During the last decades, microclimate improvement of plastic greenhouses has caught the attention of researchers worldwide due to the need to optimise the conditions under which crops are grown within these structures. The research has mainly focused on the study of sidewall and rooftop vents configurations to improve their design in terms of dimensions and position (Kacira et al., 1998; Bartzanas et al., 2004; Molina-Aiz et al., 2006; He et al., 2015). At present, modelling complex phenomena such as the natural ventilation of greenhouses is possible due to the ever-growing computing power of modern workstations and the development of advanced numerical techniques. Computational fluid dynamics (CFD) is a tool for simulating fluid flow systems as well as the interaction of the fluid with solid bodies by solving the equations of fluid motion (Blazek, 2015). Worldwide, CFD has become the preeminent tool to model and design ventilation systems by delivering realistic simulations of the inside airflow, mass and heat 
transfer in greenhouses (Norton et al., 2007). Any commercial package divides the CFD modelling process into three pre-defined environments, namely pre-processing, solving and post-processing. The pre-processing stage includes problem consideration, geometry definition, mesh development, physical properties setup and the solving techniques and parameters specification (Norton et al., 2007). Regularly, during the pre-processing stage of a ventilation analysis, the greenhouse geometry, either in $2 \mathrm{D}$ or $3 \mathrm{D}$, is embedded into a large computational domain to represent the surroundings. This large computational domain around the greenhouse must be secured to allow the natural airflow.

Therefore, the greenhouse geometry is the only physical object included in the computational domain. While this could be adequate for design purposes, the performance of the ventilation system can be compromised when the greenhouse is built in a realworld setting. Nearby buildings and infrastructure may affect the ventilation rate of a greenhouse and limit the air exchange with the exterior. To our knowledge, only a handful of greenhouse ventilation studies have considered the presence of other objects within the computational domain. For instance, Fatnassi et al. (2006) analysed the optimisation of greenhouse insect screening using an experimental greenhouse coupled to a building and with a cypress hedge on one side of the greenhouse. However, the effect of these objects on the greenhouse vents performance was not discussed since it was not the purpose of the study. Majdoubi et al. (2009) developed a CFD 3D model to predict the daytime airflow of a large-scale commercial greenhouse. Another greenhouse, located east to the one under study, was placed within the computational domain. Since the direction of the air entering the greenhouse was west east, the influence of the neighbour greenhouse over the studied one was not considered.

Conversely, since the late 70's, the wind loads and flow fields have been investigated for low-rise buildings normally built in large groups. Recently, Kim et al. (2015) found that the shielding effect of nearby buildings increase significantly with area density and recommended wind engineers to be cautious in their choices of aerodynamic coefficients. The study of the flow field and mutual interference of densely clustered high-rise buildings indicated that wind-induced aerodynamic interference can be negligible or not depending if the buildings are located downstream or upstream from the studied one (Dongmei et al., 2017). For large cooling towers, characterised as thin-wall structures, it has been demonstrated that the wind pressure distribution is more complex when they are arranged into clusters than the one of an isolated tower (Zhao et al., 2018).

In order to optimise the design of a passively ventilated plastic greenhouse, the objective of the present work was to analyse the influence of the natural surroundings on the air exchange rate and thermal performance of two plastic greenhouses. To this purpose, a 2D CFD model was developed and validated for a real scale greenhouse prototype under the conditions of the Bogota plateau (Colombia).

\section{Materials and methods}

\section{Greenhouses description}

To evaluate the influence of the natural surroundings on the airflow of plastic greenhouses we selected two greenhouse designs, namely the standard greenhouse used by most Colombian growers $(T C G)$ and an optimised greenhouse design $(O G)$. The
$T C G$ greenhouse is a saw tooth type greenhouse featuring a permanently leeward open ridge, which in combination with adjustable openings in the sidewalls conformed the natural ventilation system. The $O G$ greenhouse is higher with wider spans and features windward and leeward open ridges combined also with sidewalls vents. A vertical plastic deflector of $1.87 \mathrm{~m}$ in length divides the open ridge ventilation in two sections forcing the passing air to enter the greenhouse area. The main features of the two greenhouses are presented in Table 1.

\section{Site description}

The area of the aforementioned greenhouses designs was limited to ca. $3000 \mathrm{~m}^{2}$ due to an available piece of land matching that area at the Centro de Bio-Sistemas (45'04" N, -7400'48' W, 2620 m.a.s.1.) of the Universidad Jorge Tadeo Lozano located in the municipality of Chía, nearby Bogota, Colombia's capital city. This area is enclosed by a series of greenhouses, tree lines and hedgerows, mimicking the situation faced by growers when they decide to start or expand their business in densely populated areas such as the peri-urban surroundings of Bogota.

\section{Numerical simulation}

CFD modelling is based on the solution of the equations that govern the moment, energy and continuity applied, in this case, to the airflow inside the greenhouse. These equations can be represented as convection-diffusion equations of a compressible fluid in a two-dimensional (2D) field as follows:

$$
\frac{\partial \rho \phi}{\partial t}+\nabla(\rho \phi \vec{v})=\Gamma \nabla^{2} \phi+S_{\phi}
$$

where $\rho$ is the density of the fluid $\left(\mathrm{kg} \mathrm{m}^{-3}\right), \nabla$ is the Laplace operator, $\phi$ represents the concentration variable, $\vec{v}$ is the velocity vector $\left(\mathrm{m} \mathrm{s}^{-1}\right), \Gamma$ is the diffusion coefficient $\left(\mathrm{m}^{2} \mathrm{~s}^{-1}\right)$ and $S_{\phi}$ represents the source term (Piscia et al., 2012). For a more detailed description of the principles of CFD and its governing equations the reader is referred to the reviews carried out by Norton et al. (2007) and Norton et al. (2006).

Table 1. Main features of the two greenhouse designs under study.

\begin{tabular}{lcc} 
Characteristic & TCG & OG \\
Area $\left(\mathrm{m}^{2}\right)$ & 2992 & 3025 \\
Width $(\mathrm{m})$ & 54.4 & 55 \\
\hline Length (m) & 55 & 55 \\
Number of spans & 8 & 5 \\
\hline Span width (m) & 6.8 & 11 \\
Minimum height under gutter (m) & 3.3 & 4.4 \\
\hline Maximum height under gutter (m) & 4.7 & 6.4 \\
Minimum height at ridge (m) & 5.5 & 8.07 \\
\hline Maximum height at ridge (m) & 6.7 & 10.2 \\
Length of the rooftop vent (m) & 0.6 & 1.6 \\
\hline Rooftop vent area $\left(\mathrm{m}^{2}\right)$ & 264 & 440 \\
Sidewall vent area $\left(\mathrm{m}^{2}\right)$ & 557.8 & 792 \\
\hline Total ventilation index* (\%) & 28.6 & 40.7 \\
Rooftop ventilation index ${ }^{\circ}(\%)$ & 8.8 & 14.6 \\
\hline
\end{tabular}

$T C G$, tooth type greenhouse; $O G$, optimised greenhouse. ${ }^{*}$ Total ventilation index = Vents area/Area; ${ }^{\circ}$ Rooftop ventilation index $=$ Rooftop vent area/Area. 
This set of equations was solved by using the ANSYS Fluent software (v. 17.0). The turbulent nature of the airflow was simulated using the standard $k-\varepsilon$ turbulence model, which is based on two main equations, one for $k$ representing kinetic energy and the other for $\varepsilon$ representing the rate of dissipation in time and volume units. This model has been the most used and validated in studies focused on greenhouses demonstrating adequate precision (Fatnassi et al., 2006). All the simulations considered the energy equation, which allowed analysing the scalar field of temperatures inside the greenhouse. Likewise, the Boussinesq approach was considered in order to evaluate the phenomenon of air buoyancy.

The selected method to solve the fluid flow equations was the finite volume method, in which the result is obtained through the discretisation and integration of the transport equations through the division of the computational domain in an unstructured mesh.

\section{Mesh generation}

The initial step was the generation of geometric models that represented the cross section of the studied greenhouses and their surroundings reflecting the real experimental conditions. These geometric models were used to analyse the behaviour of the airflow and the temperature inside each greenhouse. Each greenhouse cross section was included within a large computational domain in order to guarantee that the numerical solution of the flow field outside the greenhouse will not be affected, and to allow an appropriate definition of the atmospheric boundary layer. The dimensions of the computational domain were $60 \mathrm{~m}$ height and $310 \mathrm{~m}$ length as shown in Figure 1. This size was determined following the CFD guidelines for calculating the wind environment around buildings according to Tominaga et al. (2008). These authors established that the lateral and upper limits should be at a minimum distance of $5 \mathrm{H}$ of the greenhouse, where $\mathrm{H}$ is the height of the target greenhouse. The outlet flow limit must be set at a minimum distance of $10 \mathrm{H}$ behind the greenhouse. The computational domain was composed by a grid of square elements divided into 315,476 cells for TCG and 313,742 cells for $O G$. These numbers of elements were obtained after verifying the independence of the airflow numerical solution to mesh sizes with a higher and lower number of elements according to the procedure reported by He et al. (2017). Each of these meshes was built using the ANSYS software package (v. 17.0).

A fundamental criterion to establish the accuracy of the solutions obtained through CFD is the quality of the mesh. The quality parameters evaluated were the size of the cells and the variation of the cell-to-cell size, finding that $98.3 \%$ and $98.76 \%$ of the mesh cells for $T C G$ and $O G$, respectively, were within the high-quality range (0.95-1). Orthogonal quality was also evaluated, yielding values of 0.93 for $T C G$ and 0.95 for $O G$, results that were classified within the high-quality range (Flores-Velázquez et al., 2015). The convergence criteria of the model were established at a value of $10^{-8}$ for the energy equation and at $10^{-6}$ for the continuity, momentum and turbulence equations (Baxevanou et al., 2017).

\section{Boundary conditions}

The left and right limits of the computational domain were established as limits of air intake or pressure output depending on the scenario under consideration. A uniform wind speed profile was considered, evaluating speeds equal or below $1.28 \mathrm{~m} \mathrm{~s}^{-1}$ and a temperature of $292.7 \mathrm{~K}$. This wind speed range and temperature are predominant in the study area during daylight hours. These values were established from a climatic characterisation carried out with historical data recorded during a period of six years.

The upper part of the domain was fixed with symmetrical properties so as not to generate friction losses of the airflow in contact with this surface. The simulations considered the atmospheric characteristics of the municipality of Chia such as an atmospheric pressure of $74980 \mathrm{~Pa}$ and gravity of $9.81 \mathrm{~m} \mathrm{~s}^{-1}$. Other parameters considered for the boundary conditions were the air viscosity (1.7E-05 kg m $\mathrm{kg} \mathrm{s}^{-1}$ ), cover temperature $(300.1 \mathrm{~K})$, greenhouse bare soil temperature at $10 \mathrm{~cm}$ depth $(301.1 \mathrm{~K})$ and the external floor temperature $(295 \mathrm{~K})$. The boundary conditions of the materials involved in the simulation domain are presented in Table 2. The lower part of the domain was considered as soil and the structure of the greenhouse was set as a wall boundary condition as reported by Baeza (2007), applying the physical and thermal properties of polyethylene taken from Mesmoudi et al. (2017). The model did not include any crop and additionally, the greenhouse was assumed to be hermetic. These simplifications are valid since the errors that may arise will have the same degree of magnitude for each scenario. To simulate the atmospheric boundary layer, we generated a logarithmic wind speed profile for the inlet boundary (Richards and Hoxey, 1993). This profile was linked to the main CFD module through a user-defined function, according to the following equation:

$$
v(y)=\frac{v^{*}}{K} \ln \left(\frac{y+y_{o}}{y_{o}}\right)
$$

where $v(y)$ is the average wind speed above the ground level, $y_{0}$ represents the roughness of the surface that for this case was established at $0.0161 \mathrm{~m}$ in function of the local terrain (Wieringa, 1992), $v^{*}$ is the friction speed and $K$ is the von Karman constant with a value of 0.42 .

\section{Scenarios}

The effect of the natural surroundings on the ventilation rates and thermal behaviour of the two greenhouses was analysed assuming the presence (S1) or not (S2) of obstacles around the greenhouses and at three wind speeds (A: 0.02 ; B: 0.55 ; C: $1.28 \mathrm{~m}$ $\left.\mathrm{s}^{-1}\right)$. For all the simulated scenarios, both rooftop and side wall vents were kept fully open. This in order to select the appropriate greenhouse model for the study area. For the scenarios including the natural surroundings, the computational domain included three consecutive multi-span greenhouses to the right of the studied one. Two of these greenhouses were the same saw tooth type as $T C G$, while the other one was a four-span glasshouse equipped only with

Table 2. Physical properties of the materials included in the computational domain.

\begin{tabular}{lccc} 
Material & Density $\left(\mathrm{kg} \mathrm{m}^{-3}\right)$ & Thermal conductivity $\left(\mathrm{W} \mathrm{m}^{-1} \mathrm{~K}^{-1}\right)$ & Specific heat $\left(\mathrm{J} \mathrm{kg}^{-1} \mathrm{~K}^{-1}\right)$ \\
Air & 1.225 & 0.0242 & 1006.43 \\
Polyethylene & 923 & 0.38 & 2300 \\
\hline Soil & 1300 & 1.0 & 800 \\
\hline
\end{tabular}


rooftop ventilation. To the left of the greenhouse, a tree line $11.5 \mathrm{~m}$ tall was present and we treated it as a porous medium (Figure 1).

\section{Model validation}

The validation of the CFD model was made through the comparison between the results of the simulations of the thermal behaviour of the greenhouse and the experimental record of the temperature inside the real scale $O G$ greenhouse. The greenhouse kept the dimensions of the virtual design and its longitudinal axis was oriented in the East-West direction.

The external climate was recorded by a meteorological station (Vantage Pro2 Plus, Davis Instruments, Hayward, CA, USA) located $10 \mathrm{~m}$ to the west of the greenhouse. The station integrated sensors of global radiation, temperature, relative humidity, precipitation, wind speed and direction placed at $2 \mathrm{~m}$ height. The greenhouse air temperature was recorded by means of five T-type thermocouples (copper-Constantan) connected to an equal number of data loggers (Cox-Tracer Junior, Escort DLS, Edison, NJ, USA). The set of thermocouples were evenly deployed along the transverse axis of the greenhouse and at the midpoint of the longitudinal axis. placed in white PVC cylinders to reflect direct sunlight at a height of $1.5 \mathrm{~m}$ from the ground surface. The recording stations both outside and inside the greenhouse recorded data every 10 minutes.

Field data used for validation was recorded for a period of 27 days during November and December 2016 and only daylight data was used for the CFD model validation. During this period, the ventilation configuration of the prototype greenhouse and the neighbouring greenhouses resembled the simulated ventilation configuration used by the CFD model.

\section{Results and discussion}

\section{Greenhouses without natural surroundings}

The results for the idealised setup in which the greenhouses are located within a free obstacle area are presented in Figure 2 for the corresponding scenarios of $T C G$ and in Figure 3 for $O G$ scenarios.
Under this setup, the internal airflow exhibited a relatively homogeneous condition and a low-temperature gradient (DT) between the interior and the exterior for both greenhouses.

The numerical simulations allowed determining the ventilation rate $\left(\Phi, \mathrm{m}^{3} \mathrm{~m}^{-2} \mathrm{~s}^{-1}\right)$ by integrating the air velocity in each of the greenhouse vents. For the TCGS1 scenarios, $\Phi$ ranged between 0.009 and $0.046 \mathrm{~m}^{3} \mathrm{~m}^{-2} \mathrm{~s}^{-1}$ for external wind speeds of 0.02 and $1.28 \mathrm{~m} \mathrm{~s}^{-1}$ respectively. Despite the greenhouse is not surrounded by any objects, the $\Phi$ are suboptimal for the scenarios with wind speeds equal or below $0.55 \mathrm{~m} \mathrm{~s}^{-1}$. According to ASABE (2008), the recommended $\Phi$ for naturally ventilated greenhouses should be at least $0.04 \mathrm{~m}^{3} \mathrm{~m}^{-2} \mathrm{~s}^{-1}$. The DT for these scenarios ranged between 1.1 and $3.9 \mathrm{~K}$ as a function of the wind speed.

The results for the OGS1 scenarios at different wind speeds indicated $\Phi$ values ranging from 0.062 to $0.164 \mathrm{~m}^{3} \mathrm{~m}^{-2} \mathrm{~s}^{-1}$. These $\Phi$ values increased with respect to the TCG scenarios, due to: i) an increment of $17.4 \%$ in the proportion between roof and sidewall vents areas; and ii) the general increase in the ventilation indexes normally used in passive greenhouses such as the rooftop ventilation index and the total ventilation index (Table 1). The rooftop ventilation index for the $O G$ greenhouse represented a $65 \%$ increment as compared to the index for the TCG greenhouse, resulting in a direct effect on the ventilation rates, as previously shown by Romero-Gómez et al. (2010). On the other hand, the total ventilation index of $40.7 \%$ was significantly higher than the general recommendation for passive greenhouses to be equal to $30 \%$ (FAO, 2002). The temperature gradient for the $O G$ greenhouse at different wind speeds ranged between 0.5 and $1.6 \mathrm{~K}$. These temperature gradients were lower than those observed for the $T C G$ scenarios due to the increased ventilation rates of the $O G$ greenhouse. Looking at the results for both greenhouses, it was evident the inverse relationship between $\Phi$ and DT.

\section{Greenhouses including natural surroundings}

The wind speed profiles and temperature distribution maps for the scenarios where the greenhouses are surrounded by objects indicated a generalised decrease of the internal airflows (Figures 4 and 5). This translates into lower $\Delta \mathrm{T}$ values and a greater heterogeneity of the temperature in comparison with the greenhouses scenarios excluding the natural surroundings.

The behaviour of the natural ventilation in the TCG green-
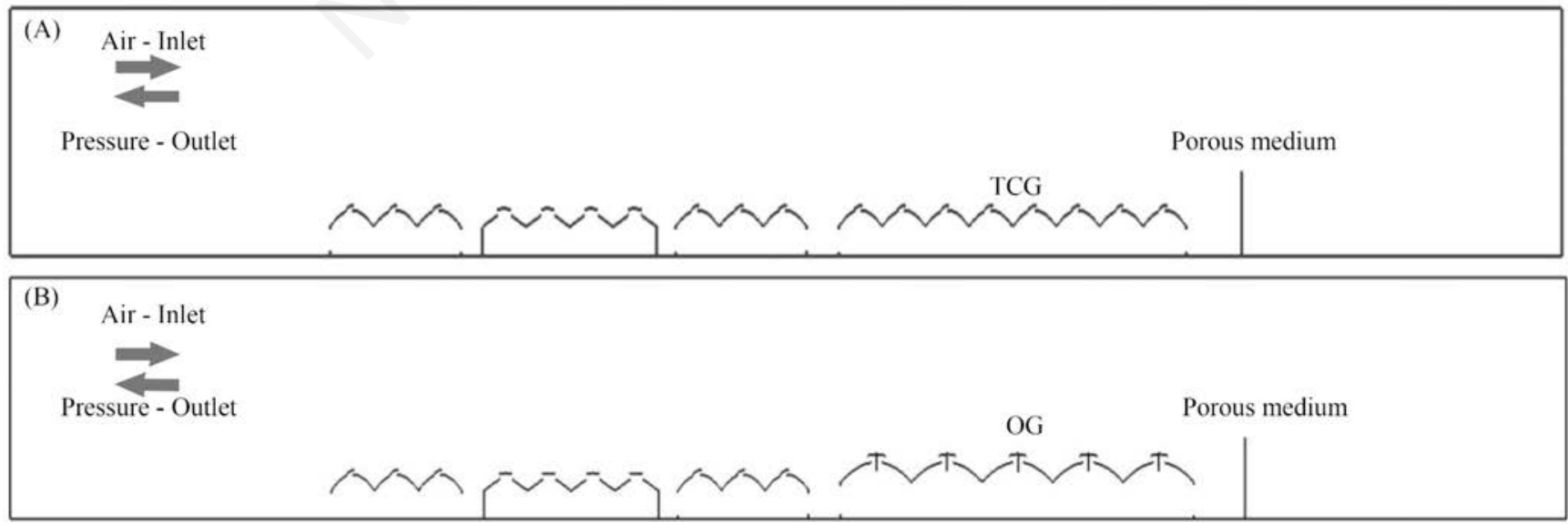

Figure 1. Computational domain of the (A) tooth type greenhouse (TCG) and (B) optimised greenhouse $(O G)$ greenhouse designs including the presence of the natural surroundings. 
house presented a greater sensitivity to the presence of obstacles on its sides; the value of $\Phi$ for the TCGS2 simulations ranged between 0.006 and $0.034 \mathrm{~m}^{3} \mathrm{~m}^{-2} \mathrm{~s}^{-1}$, for the lowest and the highest wind speeds included in the simulations, respectively. These results represent a decrease of 33 and $26 \%$ in comparison with the $\Phi$ obtained for the TCGS1 scenarios.

The analysis of the air flows for the $T C G$ scenarios indicated that for wind speeds below $0.27 \mathrm{~m} \mathrm{~s}^{-1}$ (Figure 4), the outside cold air entered the greenhouse through the sidewall ventilations from the two sides, and moves through the lower area displacing the hot air to the fixed openings of the roof ventilation. This is a characteristic behaviour for low wind speeds where the thermal effect predominates over the wind effect of natural ventilation (Haslavsky et al., 2006). A two-step roof greenhouse similar to the $O G$ design of the present work yielded a 39\% higher air flow rate at the roof opening section and a maximum temperature $4^{\circ} \mathrm{C}$ less than that of the arch type greenhouse model commonly used for sweet peppers in Thailand (Limtrakarn et al., 2012). As stated by Mistriotis et al.
(1997), a high ventilation efficiency is required particularly when low wind speeds coincide with high temperatures, therefore, attention should be paid to the ventilation efficiency under low wind speed conditions.

In the case of the $O G$ greenhouse, the $\Phi$ results were less affected by the presence of obstacles around the structure. On average, the $\Phi$ decreased $3.2 \%$ at the lowest wind speed of $0.02 \mathrm{~m} \mathrm{~s}^{-1}$ while the decrease at the higher wind speed $\left(1.28 \mathrm{~m} \mathrm{~s}^{-1}\right)$ was only $3 \%$. The positive behaviour of the natural ventilation in the $O G$ greenhouse is attributed to a greater rooftop ventilation area and to the presence of vents openings on each side. These features restrict the negative effects that the surrounding objects impose on the internal greenhouse airflow (Baeza et al., 2014). The combination of rooftop and sidewall ventilations maximised the natural ventilation effect mainly under low outdoor wind speed conditions $(<1.5$ $\mathrm{m} \mathrm{s}^{-1}$ ), as stated by Baeza et al. (2009).

The scenarios including the natural surroundings resulted in higher $\Delta \mathrm{T}$ for both greenhouse types, mainly as a result of the
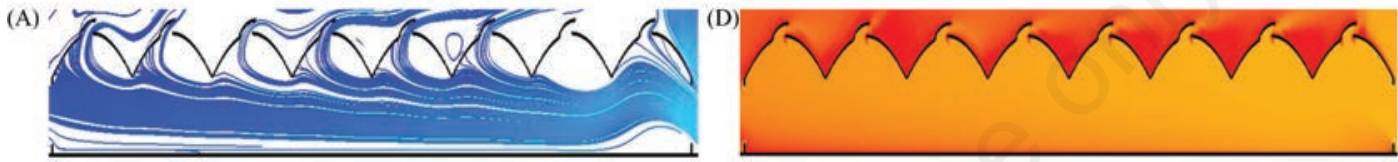

(B)
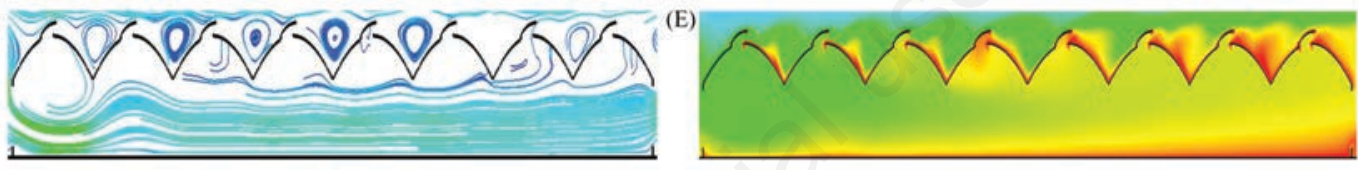

(C)
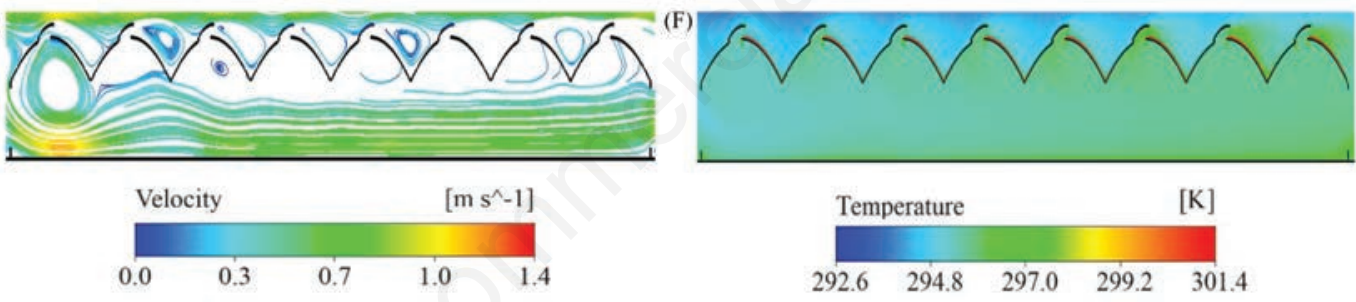

Figure 2. Wind speed (A, B, C) and temperature (D, E, F) profiles of the simulations carried out for the tooth type greenhouse without the presence of natural surroundings under wind speeds of $0.02(\mathrm{~A}, \mathrm{D}), 0.55(\mathrm{~B}, \mathrm{E})$ and $1.28(\mathrm{C}, \mathrm{F}) \mathrm{m} \mathrm{s}^{-1}$.
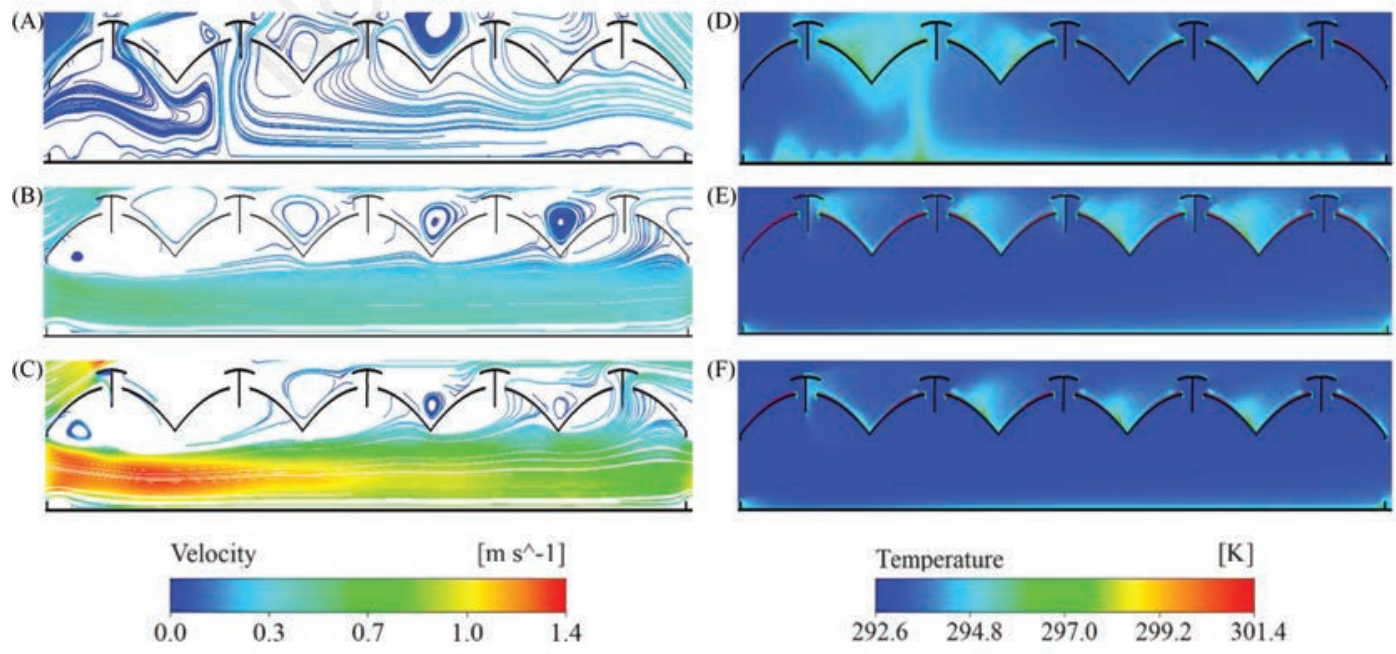

Figure 3. Wind speed (A, B, C) and temperature (D, E, F) profiles of the simulations carried out for the optimised greenhouse without the presence of natural surroundings under wind speeds of $0.02(\mathrm{~A}, \mathrm{D}), 0.55(\mathrm{~B}, \mathrm{E})$ and $1.28(\mathrm{C}, \mathrm{F}) \mathrm{m} \mathrm{s}^{-1}$. 

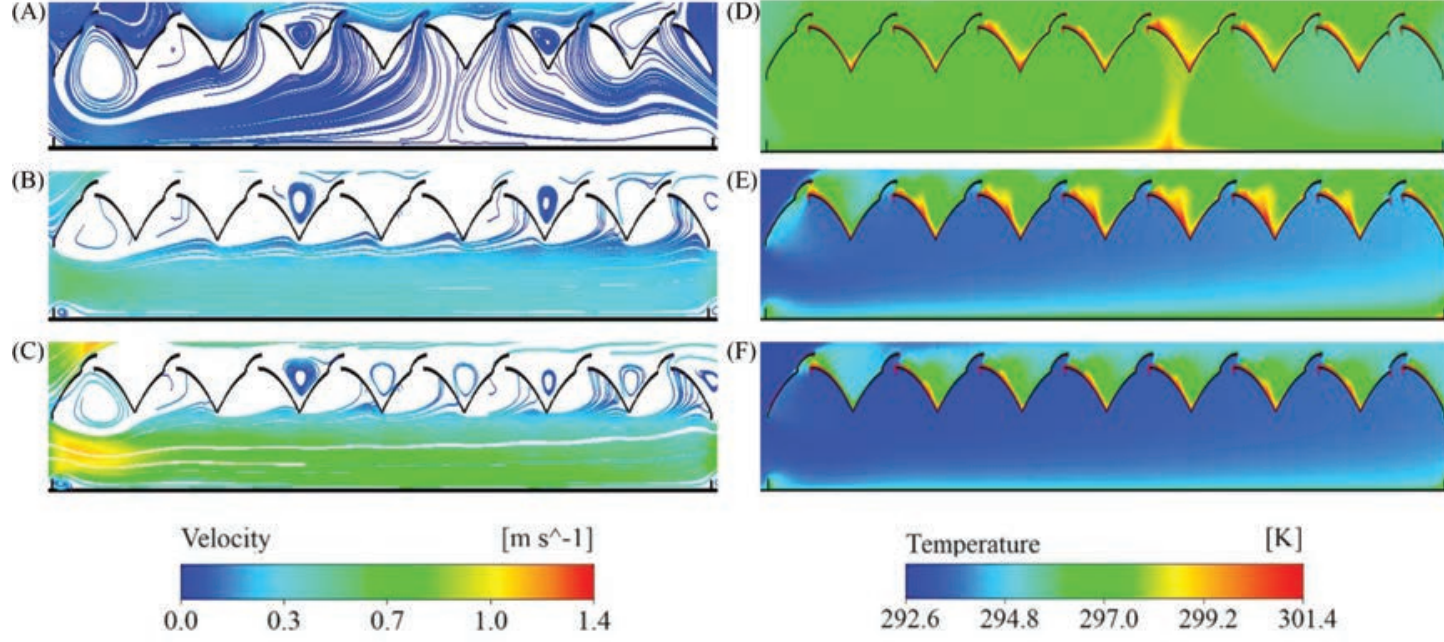

Figure 4. Wind speed (A, B, C) and temperature (D, E, F) profiles of the simulations carried out for the tooth type greenhouse with the presence of natural surroundings under wind speeds of $0.02(\mathrm{~A}, \mathrm{D}), 0.55(\mathrm{~B}, \mathrm{E})$ and $1.28(\mathrm{C}, \mathrm{F}) \mathrm{m} \mathrm{s}^{-1}$.
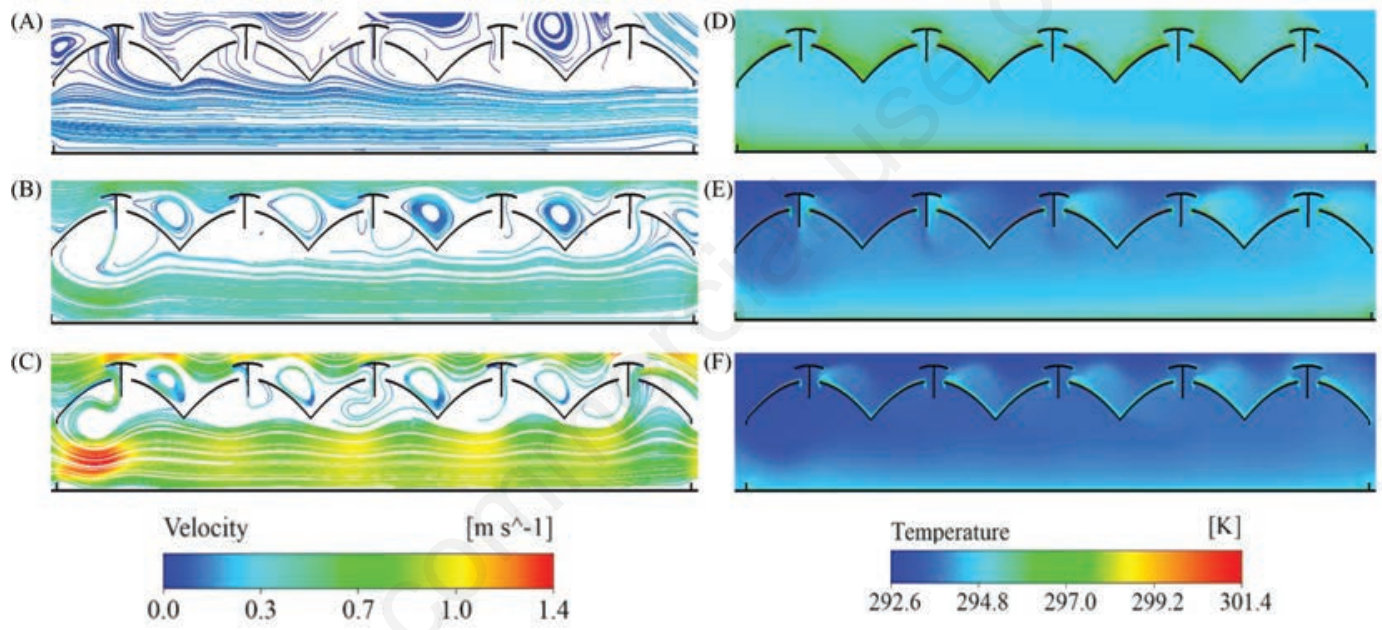

Figure 5. Wind speed (A, B, C) and temperature (D, E, F) profiles of the simulations carried out for the optimised greenhouse with the presence of natural surroundings under wind speeds of $0.02(\mathrm{~A}, \mathrm{D}), 0.55(\mathrm{~B}, \mathrm{E})$ and $1.28(\mathrm{C}, \mathrm{F}) \mathrm{m} \mathrm{s}^{-1}$.
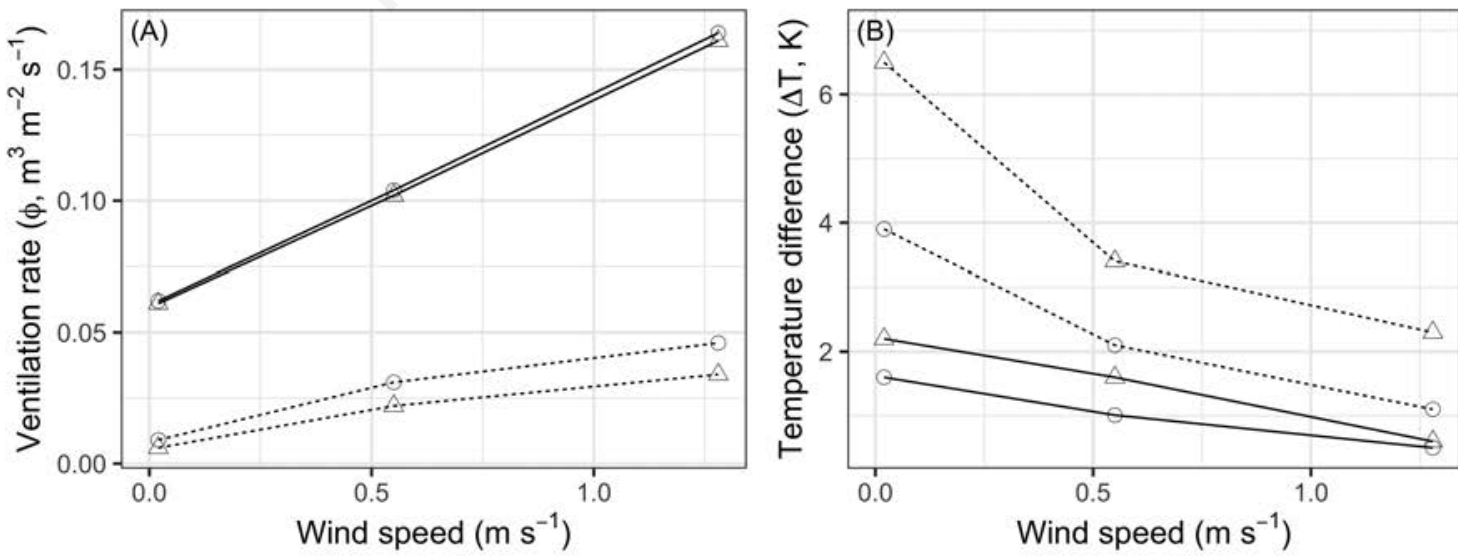

Greenhouse

-. OGS

Obstacles

$\triangle$ No

Figure 6. Ventilation rates (A) and thermal difference (B) between the interior and the exterior of the greenhouses at different wind speeds and under the presence or not of obstacles. 
lower ventilation rates. The $\Delta \mathrm{T}$ calculated for the scenarios of the $T C G$ greenhouse was between 2.6 and $1.2 \mathrm{~K}$ higher under the scenario with natural surroundings at the wind speeds of 0.02 and 1.28 $\mathrm{m} \mathrm{s}^{-1}$ (Figure 6), respectively. The $\Delta \mathrm{T}$ of the $O G$ greenhouse presented a lower degree of variation, with $\Delta \mathrm{T}$ that only exceeded those observed at the OGS1 scenarios by 0.6 and $0.1 \mathrm{~K}$ for the same wind speeds (Figure 6). These results confirmed the improved performance of the natural ventilation in the $O G$ greenhouse. When the internal microclimate of a greenhouse shows a heterogeneous condition affects physiological processes such as transpiration and photosynthesis (Bartzanas et al., 2004), leading to agronomic consequences such as the lack of uniformity both in quantity and quality of the harvested product.

\section{Computational fluid dynamics model validation}

To check the validity of the CFD simulations, we installed an array of sensors within a real scale prototype of the $O G$ greenhouse. The temperature profiles at different wind speeds registered during the field data collection period are presented in Figure 7. Despite the wind speed, the temperature profile exhibited the same trend along the transverse axis of the greenhouse. The air entered with a higher temperature than the one observed on the other end of the greenhouse. A decreasing trend of the temperature was observed along the line of sensors. The highest temperature difference was $2.8 \mathrm{~K}$ for the wind speed intervals $(0.4,0.9)$ and $(0.9,1.3)$ $\mathrm{m} \mathrm{s}^{-1}$. At the lowest wind speed interval, the temperature difference across the greenhouse was $1.9 \mathrm{~K}$ while at the highest wind speed interval $(1.3,2.7) \mathrm{m} \mathrm{s}^{-1}$ the temperature difference was 1.6 $\mathrm{K}$. These results were compared qualitatively with those from the CFD simulations (Figure 5). The CFD simulations showed the same temperature trend along the transverse axis. According with the simulations, at higher wind speeds the temperature differences increased up to values around $2 \mathrm{~K}$. While the CFD simulations were carried out only for a wind speed up to $1.28 \mathrm{~m} \mathrm{~s}^{-1}$, the wind speeds registered on the field reached a maximum of $2.7 \mathrm{~m} \mathrm{~s}^{-1}$. Despite the dynamic behaviour of the climate in the real situation, the temperature trends within the greenhouse resembled the temperature pattern resulting from the CFD modelling. However, it should be noted that this validation procedure is an indirect one since we were not able to measure the air speed within the greenhouses. Therefore, based on the available equipment, we registered the temperature profile within the greenhouse and used it as the variable to assess the results of the CFD simulations. When wind

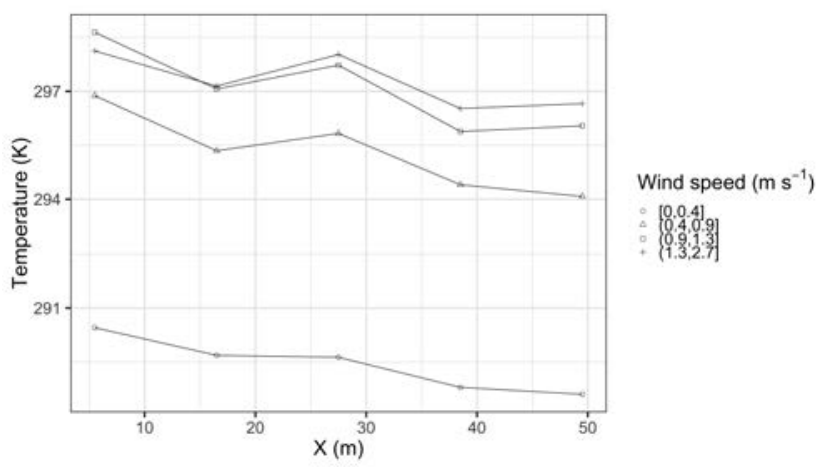

Figure 7. Temperature profiles within the optimised greenhouse prototype at different wind speed intervals used for the validation of the computational fluid dynamics simulations. and buoyancy driving forces occur simultaneously under uncontrolled meteorological conditions make it hard to analyse the influence of each parameter and to draw general conclusions (Nore et al., 2010). Nevertheless, since CFD couples temperature and velocity fields, the use of on-site temperature measurements is appropriate to get an approximate idea on how well the CFD model is representing the airflow within the greenhouse.

\section{Conclusions}

The expansion of greenhouse horticulture in periurban areas is facing challenges such as the availability of land. New greenhouse facilities have to be accommodated around overcrowded areas impacting the performance of their ventilation system, especially when the greenhouse is passively ventilated. As demonstrated in this work, the ventilation of a greenhouse with restricted ventilation areas is heavily reduced when its surroundings are filled with neighbouring objects high enough to limit the free circulation of the air into the greenhouse. This ventilation restriction is exacerbated under low wind speed conditions, such as those observed in the Bogota plateau.

Increasing the greenhouse ventilation areas, in particular those from the roof, allows for an improved air exchange with the outside, overcoming the restrictions imposed by the surrounding environment. Once the ventilation rate of a greenhouse is increased, the air exchange with the outside allows a more uniform climate condition within the cropping area. While CFD has demonstrated to be a powerful tool to simulate the inside climate of several greenhouses, care must be taken when designing greenhouses without considering the natural environment in which the greenhouse will be placed. The CFD method has the available tools to include any kind of object affecting the ventilation of a greenhouse, therefore a more realistic modelling and simulation job can be carried out.

\section{References}

ASABE. 2008. Heating, ventilating and cooling greenhouses. ASABE standards, ANSI/ASAE EP406.4 JAN2003 (R2008). American Society of Agricultural and Biological Engineers, St. Joseph, USA.

Baeza E. 2007. Optimización del diseño de los sistemas de ventilación en invernaderos tipo parral. $\mathrm{PhD}$ thesis. Universidad de Almería, Almería, Spain.

Baeza E.J., Pérez-Parra J.J., Montero J.I., Bailey B.J., López J.C., Gázquez J.C. 2009. Analysis of the role of sidewall vents on buoyancy-driven natural ventilation in parral-type greenhouses with and without insect screens using computational fluid dynamics. Biosyst. Eng. 104:86-96.

Baeza E., Montero J.I., Pérez-Parra J., Bailey B.J., López J.C., Gázquez J.C. 2014. Avances en el estudio de la ventilación natural. Documentos Técnicos No. 7. Cajamar Caja Rural, Almería, Spain.

Bartzanas T., Boulard T., Kittas C. 2004. Effect of vent arrangement on windward ventilation of a tunnel greenhouse. Biosyst. Eng. 88:479-90.

Baxevanou C., Fidaros D., Bartzanas T., Kittas C., 2017. Yearly numerical evaluation of greenhouse cover materials. Comput. Electron. Agr. [in press].

Blazek J. 2015. Introduction. In: Blazek, J. (Ed.), Computational fluid dynamics: Principles and applications. Third Edition. Butterworth Heinemann, Elsevier, Oxford, UK. pp. 1-5. 
Castilla N. 2002. Current situation and future prospects of protected crops in the Mediterranean region. Acta Hort. 582:135-147.

Dongmei H., Ledong Z., Quanshun D., Xue Z., Wei C. 2017. Aeroelastic and aerodynamic interference effects on a highrise building. J Fluid. Struct. 69:355-81.

Fatnassi H., Boulard T., Poncet C., Chave M. 2006. Optimisation of greenhouse insect screening with computational fluid dynamics. Biosyst. Eng. 93:301-12.

FAO. 2002. El cultivo protegido en clima mediterráneo. Estudio FAO Producción y protección vegetal 90. Food and Agriculture Organization of the United Nations, Rome.

FAO. 2013. Good agricultural practices for greenhouse vegetable crops. FAO plant production and protection paper 217. Food and Agriculture Organization of the United Nations, Rome.

Flores-Velásquez J., Villarreal-Guerrero F. 2015. Diseño de un sistema de ventilación forzada para un invernadero cenital usando CFD. Rev. Mex. De Cienc. Agric. 6:303-16.

Haslavsky V., Tanny J., Teitel M. 2006. Interaction between the mixing and displacement modes in a naturally ventilated enclosure. Build. Environ. 41:1755-61.

He X., Wang J., Guo S., Zhang J., Wei B., Sun J., Shu S. 2017. Ventilation optimization of solar greenhouse with removable back walls based on CFD. Comput. Electron. Agr. [in press].

He K., Chen D., Sun L., Huang Z., Liu Z., 2015. Effects of Vent Configuration and Span Number on Greenhouse Microclimate under Summer Conditions in Eastern China. Int. J. Vent. 13:381-96.

Kacira M., Short T.H., Stowell R.R. 1998. A CFD evaluation of naturally ventilated, multi-span, saw tooth greenhouses. Trans. A.S.A.E. 41:833-7.

Kim Y.C., Tamura Y., Yoon S. 2015. Proximity effect on low-rise building surrounded by similar-sized buildings. J. Wind Eng. Ind. Aerod. 146:150-62.

Limtrakarn W., Boonmongkol P., Chompupoung A., Rungprateepthaworn K., Kruenate J., Dechaumphai P. 2012. Computational fluid dynamics modelling to improve natural flow rate and sweet pepper productivity in greenhouse. Adv. Mech. Eng. 4:158563.

Majdoubi H., Boulard T., Fatnassi H., Bouirden L. 2009. Airflow and microclimate patterns in a one-hectare Canary type greenhouse: An experimental and CFD assisted study. Agric. For. Meteorol. 149:1050-62.

Mesmoudi K., Meguallati K., Bournet P. 2017. Effect of the greenhouse design on the thermal behaviour and microclimate distribution in greenhouses installed under semi-arid climate.
Heat Tran. Asian Res. 46:1294-311.

Mistriotis A., Arcidiacono C., Picuno P., Bot G.P.A., ScarasciaMugnozza G. 1997. Computational analysis of ventilation in greenhouses at zero- and low-wind-speeds. Agri. For. Meterol. $88: 121-35$.

Molina-Aiz F.D., Valera D.L., Peña A.A., Álvarez A.J., Gil J.A. 2006. Analysis of the effect of rollup vent arrangement and wind speed on Almería-type greenhouse ventilation performance using computational fluid dynamics. Acta Hort. 719:173-9.

Nore K., Blocken B., Thue J.V. 2010. On CFD simulation of windinduced airflow in narrow ventilated facade cavities: Couple and decoupled simulations and modelling limitations. Build. Environ. 45:1834-46.

Norton T., Sun D., Grant J., Fallon R., Dodd V. 2007. Applications of computational fluid dynamics (CFD) in the modelling and design of ventilation systems in the agricultural industry: A review. Bioresour. Technol. 98:2386-14.

Norton T., Sun D. 2006. Computational fluid dynamics (CFD) - an effective and efficient design and analysis tool for the food industry: A review. Trends Food Sci. Technol. 17:600-20.

Piscia D., Montero J.I., Baeza E., Bailey B.J. 2012. A CFD greenhouse night-time condensation model. Biosyst. Eng. 111:141-54.

Romero-Gómez P., Choi C.Y., Lopez-Cruz I. 2010. Enhancement of the greenhouse air ventilation rate under climate conditions of Central México. Agrociencia 44:1-15.

Reddy P.P. 2016. Protected cultivation. In: Reddy, P.P. (Ed), Sustainable crop protection under protected cultivation. Springer, Singapore. pp. 1-12.

Richards P.J., Hoxey R.P. 1993. Appropriate boundary conditions for computational wind engineering models using the k-e turbulence model. Proc. 1st Int. Symp. Comput. Wind Eng. (CWE 92), Tokyo, Japan. pp. 149-153.

Tominaga Y., Mochida A., Yoshie R., Kataoka H., Nozu T., Yoshikawa M., Shirasawa T. 2008. AIJ guidelines for practical applications of CFD to pedestrian wind environment around buildings. J. Wind Eng. Ind. Aerod. 96:1749-61.

Tuzel Y., de Zwart H.F., Sapounas A., Hemming S., Stanghellini C. 2017. Improvement of greenhouse design and climate control in Mediterranean conditions. J. Food Agric. Environ. 15:74-9.

Wieringa J. 1992. Updating the Davenport roughness classification. J. Wind Eng. Ind. Aerod. 41:357-68.

Zhao L., Zhan Y., Ge Y. 2018. Wind-induced equivalent static interference criteria and its effects on cooling towers with complex arrangements. Eng. Struct. 172:141-53. 